\title{
Application of pyrolysis residue from waste materials in black coal flotation
}

\author{
Peter Fečko $^{1 *}$, Alena Kašpárková ${ }^{1}$, Eva Pertile ${ }^{1}$, Vlastimil Kř́̌̌̌ ${ }^{2}$, Barbara Tora ${ }^{3}$, Andrzej Jarosiński ${ }^{4}$, \\ Iva Janáková ${ }^{1}$ \\ ${ }^{1}$ Technical University of Ostrava, Faculty of Mining and Geology, 17 listopadu 15, 70833 Ostrava-Poruba \\ ${ }^{2}$ Institute of Rock Structure and Mechanics AS CR, Prague, Czech Republic \\ ${ }^{3}$ AGH Kraków, Poland \\ ${ }^{4}$ Politechnika Krakowska, Poland \\ *corresponding author: e-mail address: peterfecko@vsb.cz
}

\begin{abstract}
The paper deals with the verification of the floatability of pyrolytic oils, which were obtained through the pyrolysis of waste, namely mixed plastics, tyres and waste rubber in combination with black coal from Lazy Mine, and classical collector Montanol 551 in black coal flotation. Black coal from ČSA OKD, a.s. coal preparation plant was used for flotation tests. The results imply that it is possible to produce collectors from waste materials which may be applied in the flotation of black coal. Next, the paper focused on the identification of a suitable combination of pyrolytic oils and Montanol 551 in order to reach ash content in the concentrate below $10 \%$.
\end{abstract}

Keywords: flotation, black coal, pyrolysis, plastic waste, tyre and rubber.

\section{INTRODUCTION}

Coal is a raw material mined for the purposes of numerous industries. At the beginning of the $21^{\text {st }}$ century the global significance of coal for the civilization is universal. It is used in metallurgy, power-engineering, chemistry and many other industrial branches.

Currently, mining of black coal is stagnating despite the fact that the consumption of industrial raw materials, the natural resources which are depletable by human action and not renewable, is increasing. A question arises how to deal with the issues in connection with a slump in coal mining. One possibility is as perfect preparation of mined coal as possible as well as the maximum utilization of its combustible component.

This trend represents new objectives for mineral dressing - to prepare and comprehensively use the finest coal fractions that originate from the processes of black coal preparation. The created large share of slurry fractions cannot be processed applying classical dressing methods. Those fractions then leave the preparation plant unused, they get into the circuit water of waste water treatment plants, they deteriorate the processes of sedimentation, filtration, and water courses get polluted. There are losses in valuable raw materials as coal slurries are dewatered in sludge beds or lagoons if they remain unutilized.

The technological procedures of processing of mineral and secondary raw materials, which can be used to deal with the difficult task of ensuring effective, economical and complex utilization of material resources, are flotation, flocculation or their combination, i.e. flotoflocculation ${ }^{2,3}$.

Thanks to flotation as a technological method of dressing mineral resources and secondary raw materials it is possible to deal with an uneasy task of ensuring an effective, practical and complex utilization of materials sources. Flotation belongs to the methods which permit processing of fine, non-homogeneous black-coal slurry'.

Coal flotation deals with cleaning the finest fractions of mined coal originating due to abrasion or disintegration in the course of coal mining and preparation. In practice, it is used only for the preparation of cokeable coal.
Flotation in coal preparation is a complementary method of other classification processes but very important one and often necessary, especially in connection with the ever increasing share of fine fractions due to an extended degree of mechanization of coal mining ${ }^{5,6}$.

Along with improving the selectivity of flotation it is currently possible to make use of old dumps as the source of material. There was no possible utilization for such dumps in the past. In the course of flotation, very fine fractions get separated, which would otherwise transfer into waste. Next, it is possible to apply flotation to retrieve coal for power-engineering purposes from old settling pits.

This way a significant share of waste constituent is removed from the pulp and thus it gets enriched. Selective flotation can be a final cleaning method or a part of a complex preparation process, which leads to preliminary enrichment of the pulp before further preparation process. Application of a suitable collector, which would be ecologically as well as economically interesting, makes an inseparable part of the flotation process. Therefore, it is vital to search for new collectors that would comply with the conditions in question ${ }^{8,4}$.

\section{PAPER OBJECTIVE}

The objective of the paper was research into new flotation collectors which were obtained through pyrolysis of different types of waste (mixed plastic waste, tyres and rubber) that were pyrolyzed with black coal from Lazy Mine, OKD, a.s. and a comparison with a commonly applied collector of Montanol 551, which is used in coal preparation plants in the Czech Republic and Poland. Next, the paper focused on the identification of a suitable combination of pyrolytic oils and Montanol 551 in order to reach ash content in the concentrate below $10 \%{ }^{7}$.

\section{MINERALOGICAL-PETROLOGIC CHARACTER OF THE TESTED COAL}

Coal polished sections were prepared in compliance with CSN ISO 7404-2 Standard. Maceral analysis was implemented using grain sections in compliance with CSN 
ISO 7404-3 Standard. Coal-petrographic analyses were carried out using a microscope of NU 2 of Carl Zeiss Jena in oil immersion under the following conditions: $\mathrm{n}_{\mathrm{D}}=1.515, \lambda=546 \mathrm{~nm}$ and temperature of $20^{\circ} \mathrm{C}$. In the photos of the coal polished sections the magnification scale is $50 \mu \mathrm{m}$. Petrographic analyses were carried in the laboratories of Research Institute of Arcelor Mittal, a.s. Ostrava.

Table 1 gives an evaluation of petrologic analyses, where the individual symbols mean: D - candle coal, $\mathrm{Ka}-$ baking coal of the $1^{\text {st }}$ type, $\mathrm{G}$ - gas coal, $\mathrm{Kb}$ - baking coal of the $2^{\text {nd }}$ type, - medium volatile bituminous coal, $\mathrm{T}$ - anthracite coal, $\mathrm{K} \cdot$ - low-volatile bituminous coal, $\mathrm{R}_{\mathrm{n}}$ - random reflectivity according to CSN ISO 7404-5.

Table 1. Evaluation of petrologic analysis of coal from ČSA Mine

\begin{tabular}{|cc|cc|cc|}
\hline $\begin{array}{c}\text { Maceral analysis } \\
(\%)\end{array}$ & \multicolumn{2}{|c|}{$\begin{array}{c}\text { Type analysis } \\
(\%)\end{array}$} & \multicolumn{2}{c|}{$\begin{array}{c}\text { Vitrinite reflectivity } \\
(\%)\end{array}$} \\
\hline Vitrinite: & 49.2 & $\mathrm{D}:$ & $\mathrm{Ka}:$ & $\mathrm{Rn}:$ & 1.028 \\
\hline Inertinite: & 44.8 & $\mathrm{G}: 22$ & $\mathrm{~Kb}:$ & $\mathrm{R}_{\min }:$ & 0.853 \\
\hline Liptinite: & 6.0 & $\mathrm{Z}: 60$ & $\mathrm{~T}:$ & $\mathrm{R}_{\max }:$ & 1.294 \\
\hline & & $\mathrm{Kz}: 18$ & $\mathrm{~A}:$ & $\mathrm{s}:$ & 0.113 \\
\hline
\end{tabular}

Figure 1 displays the reflectivity of black coal from the ČSA locality. Figure 2 shows a megasporinite grain and Figure 3 shows a grain of cutinite and vitrinite.

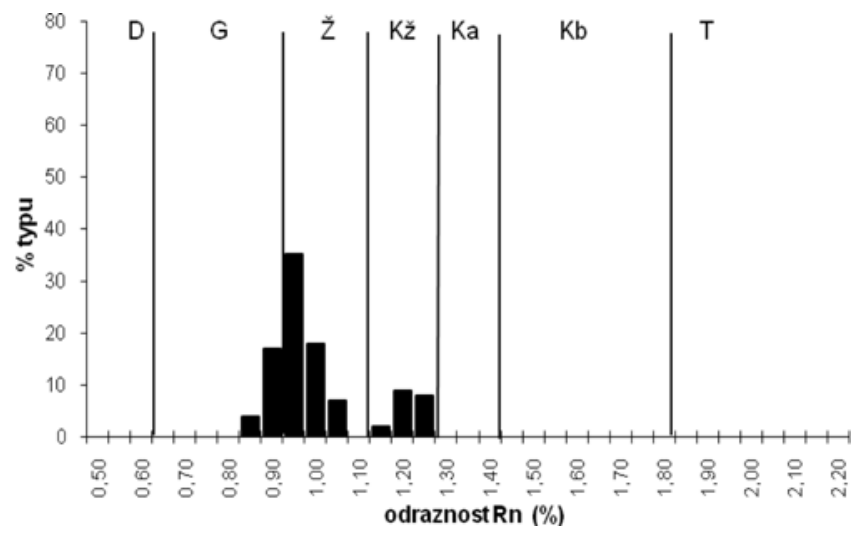

Figure 1. Reflectivity of CSA Mine black coal

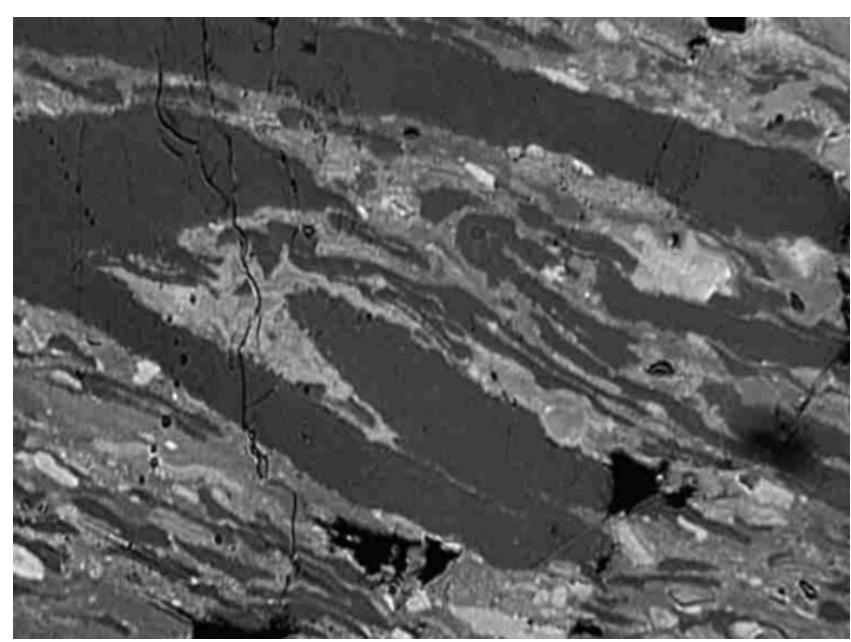

Figure 2. A megasporinite grain (CSA Mine)

\section{METHOD AND FESULTS OF PYROLYSIS TESTS}

For all the pyrolysis tests a laboratory pyrolytic unit was used, built in IRSM AS CR Prague. Pyrolysis took place in a quartz reactor ( $\varnothing 60 \mathrm{~mm}$, length $450 \mathrm{~mm}$ ) placed into a vertical tube oven controlled by a microprocessor.

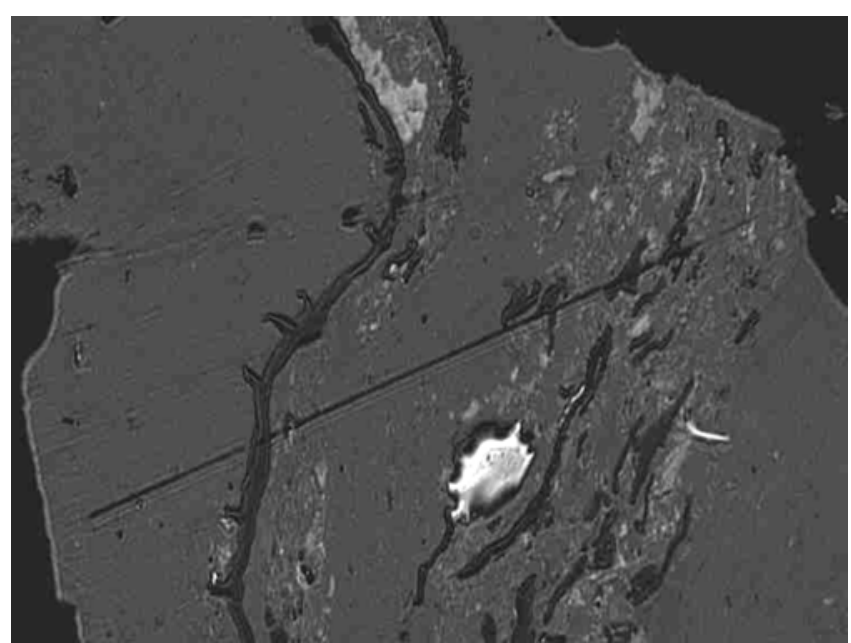

Figure 3. A grain of cutinite and vitrinite

Conditions of Pyrolysis:

Heating rate: $5 \mathrm{~K} \cdot \mathrm{min}^{-1}$ up to the final temperature of $900^{\circ} \mathrm{C}$.

Soaking time 30 minutes at $900^{\circ} \mathrm{C}$.

The sample weight was $50 \mathrm{~g}$ (grain less than $3 \mathrm{~mm}$ ). Different types of waste, such as mixed plastic waste, tyres and rubber, were used for the tests of pyrolysis.

Figure 4 shows equipment used for the pyrolysis tests.

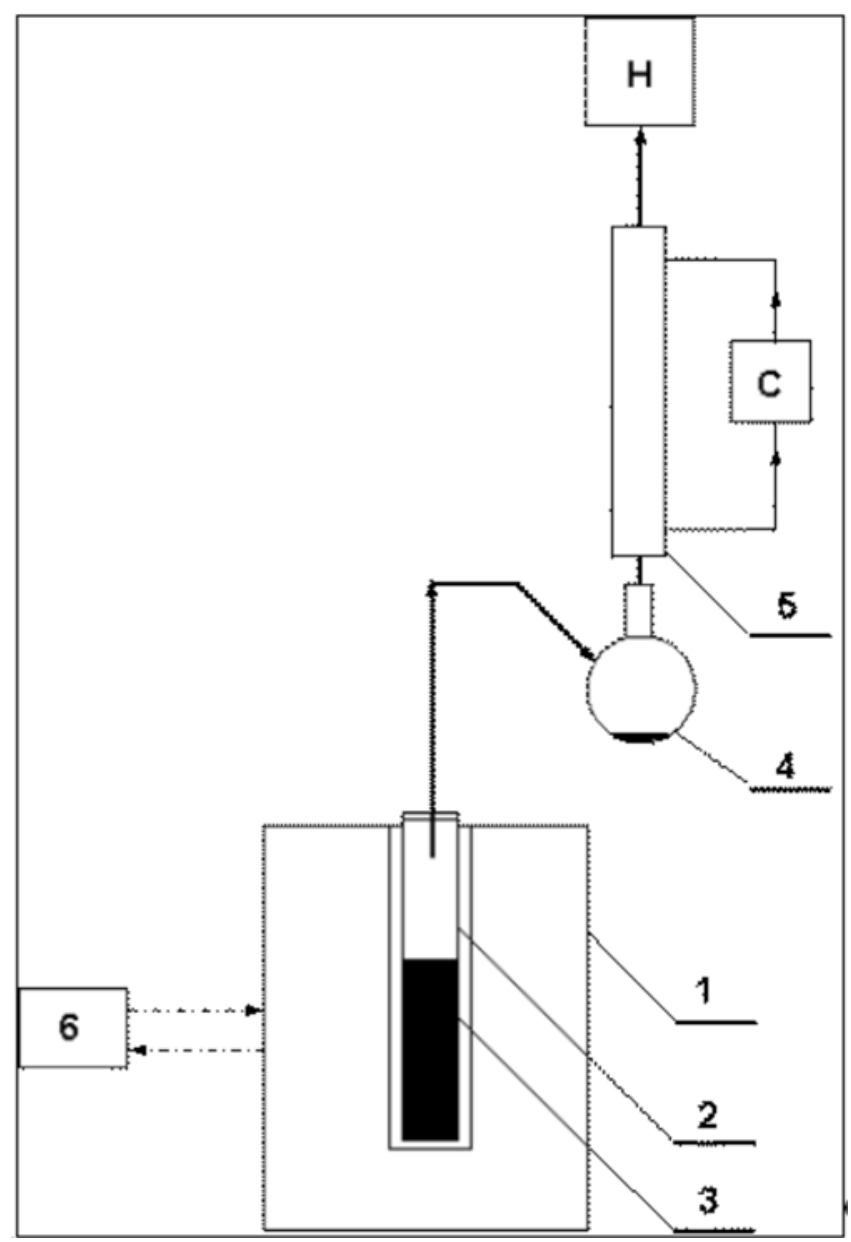

Figure 4. Laboratory pyrolytic unit. Notes: 1 - vertical tube oven, 2 - quartz reactor, 3 - pyrolyzed sample, 4 - flask with liquid products, 5 - cooler, 6 - programmable temperature control unit, $\mathrm{H}$ - gas holder with gas volume registration, C - cooling unit 
The characteristics of the obtained oils were analyzed in the laboratories of VUCHEM VSB-TU Ostrava using an infra-red (IR) spectrometer. To be illustrative, only two IR analysis results are given, namely of sample GSP16 (oil obtained through the pyrolysis of mixed plastics and black coal from Lazy Mine) and sample G-PR18 (oil obtained through the pyrolysis of tyres, rubber and black coal from Lazy Mine) as shown in Figures 5 and 6.

It was $20 \%$ of mixed plastics and $80 \%$ of black coal that were used. The analysis results imply that the oil lacks the characteristic vibrations of hydroxyls in a water molecule, which means that it has a minimum water content. In the sample there is a significant representation of C-H bonds present in the unsaturated hydrocarbons (4 peaks in 2954 $-2871 \mathrm{~cm}^{-1}$ spectrum area); next, there is carbonyl in $1737-1721 \mathrm{~cm}^{-1}$ spectrum area. The presence of aromates is also possible (vibrations over $3000 \mathrm{~cm}^{-1}$, overtones around $2000 \mathrm{~cm}^{-1}$, peaks around 1600, 1500 and 1400 $\left.\mathrm{cm}^{-1}\right)$.

Pyrolysis was carried out combining $85 \%$ of black coal and $15 \%$ of tyre and waste rubber mixture. The FTIR results imply that in the band $3372 \mathrm{~cm}^{-1}$ the presence of water is possible, in bands $2953-2855 \mathrm{~cm}^{-1} \mathrm{C}-\mathrm{H}$ bonds were identified and around $1700 \mathrm{~cm}^{-1}$ band carbonyl was identified. In the sample the presence of aromates is possible (vibrations over $3000 \mathrm{~cm}^{-1}$, overtones around $2000 \mathrm{~cm}^{-1}$, peaks around 1600, 1500 and $1400 \mathrm{~cm}^{-1}$ ).

In the majority of the samples the presence of $\mathrm{C}-\mathrm{H}$ bonds was proved in saturated hydrocarbons (sharp vibration bands between 2800 and $2960 \mathrm{~cm}^{-1}$ ). The highest intensity of the peaks was in the case of a mixed plastic sample and the sample with the used combination of tyres and rubber. In the majority of the samples the presence of the carbonylic group $\mathrm{C}=\mathrm{O}$ (around $1700 \mathrm{~cm}^{-1}$ ) in ketones or carboxylic acids was determined. The presence of aromates was determined in the samples of plastics, tyres and rubber.

\section{METHODOLOGY OF THE FLOTATION TESTS}

Flotation tests were carried out in the laboratory of the Institute of Environmental Engineering of the VSB - Technical University of Ostrava using a laboratory flotation machine VRF-1, a product of RD Př́bram. It is an agitating flotation machine with an own air intake. Oils produced during pyrolysis were used to test flotation oil selectivity and were compared with Montanol 551 collector. Flotation experiments were carried out using black coal from ČSA Mine, Czech Republic.

Flotation was carried out under the following conditions:

- pulp density: $150 \mathrm{~g} / \mathrm{l}$,

- collector dose: $500 \mathrm{~g} / \mathrm{t}$,

- agitation time with agents: 1 minute,

- flotation time: 5 minutes.

\section{CONCLUSION}

The objective of the paper was the verification of the floatability of the classical collector Montanol 551 and pyrolysis oils obtained through the pyrolysis of waste,

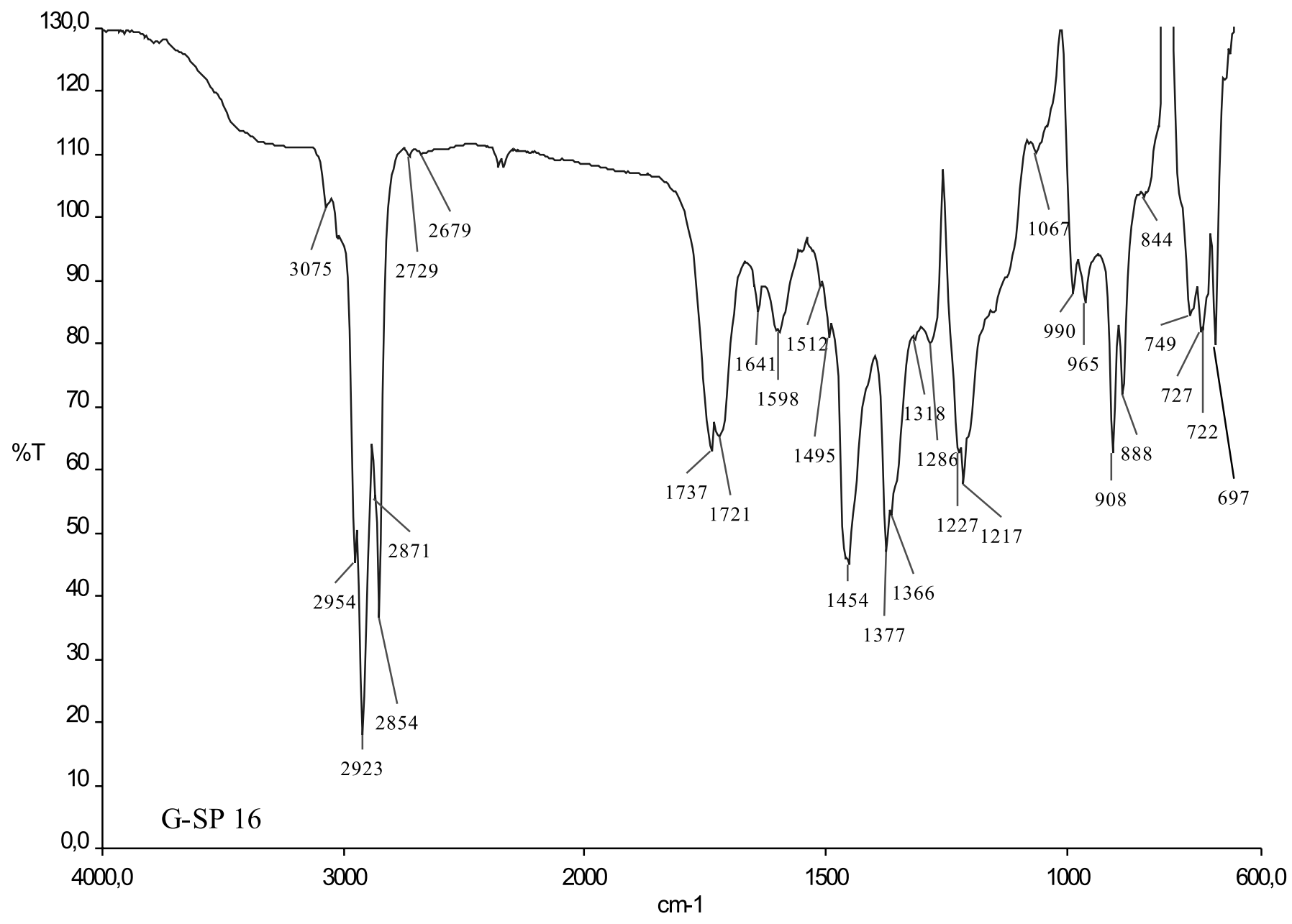

Figure 5. FTIR analysis of pyrolytic oil obtained through the pyrolysis of mixed plastics and black coal 


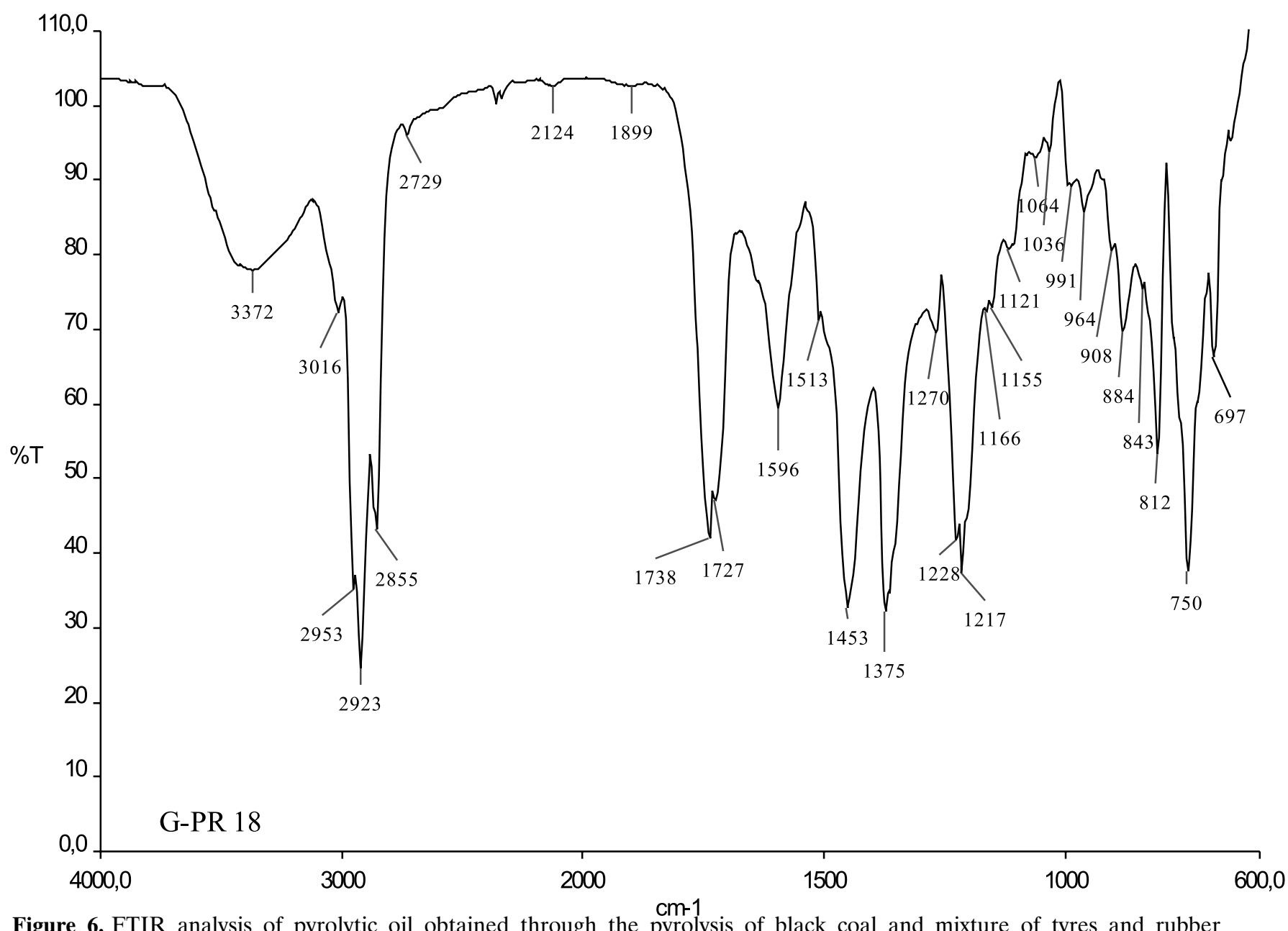

Table 2. Flotation test results with pyrolytic oils

\begin{tabular}{|c|c|c|c|}
\hline Flotation collector & & $\begin{array}{c}\text { Yield } \\
\%\end{array}$ & $\begin{array}{l}\text { Ash content } \\
\%\end{array}$ \\
\hline \multirow{3}{*}{ Montanol 551} & Concentrate & 94.02 & 8.14 \\
\hline & Tailings & 5.98 & 78.17 \\
\hline & Input & 100 & 12.33 \\
\hline \multirow{3}{*}{$\begin{array}{c}\text { G-SP16 } \\
\text { black coal from Lazy Mine + mixed plastics } 20 \%\end{array}$} & Concentrate & 78.17 & 4.67 \\
\hline & Tailings & 21.83 & 41.97 \\
\hline & Input & 100 & 12.81 \\
\hline \multirow{3}{*}{$\begin{array}{c}\text { G-SP18 } \\
\text { black coal from Lazy Mine + rubber } 15 \%\end{array}$} & Concentrate & 70.34 & 5.13 \\
\hline & Tailings & 29.66 & 24.22 \\
\hline & Input & 100 & 10.79 \\
\hline \multirow{3}{*}{$\begin{array}{c}\text { G-SP17 } \\
\text { black coal from Lazy Mine + rubber } 20 \%\end{array}$} & Concentrate & 62.57 & 8 \\
\hline & Tailings & 37.43 & 16.73 \\
\hline & Input & 100 & 11.27 \\
\hline \multirow{3}{*}{$\begin{array}{c}\text { G-PR19 } \\
\text { black coal from Lazy Mine + rubber } 15 \%\end{array}$} & Concentrate & 59.11 & 6.22 \\
\hline & Tailings & 40.89 & 21.27 \\
\hline & Input & 100 & 12.37 \\
\hline \multirow{3}{*}{$\begin{array}{c}\text { 468-PO1 } \\
\text { black coal from Lazy Mine + rubber } 30 \%\end{array}$} & Concentrate & 81.82 & 6.59 \\
\hline & Tailings & 18.18 & 44.01 \\
\hline & Input & 100 & 13.39 \\
\hline
\end{tabular}

namely mixed plastics, tyres and waste rubber, combined with Lazy Mine black coal in black coal flotation. The paper results imply that it is possible to produce collectors from waste materials which may be applied in the flotation of black coal. Combining pyrolytic oils and Montanol 551 in 1:1 proportion we succeeded in obtaining excellent quality of flotation concentrates, at the concentrate yield over $90 \%$. The quality of the concentrate is suitable as the ash content is below $10 \%$. It is thus apparent that each reduction in Montanol 551 consumption may bring a significant economic effect.

\section{LITERATURE CITED}

1. Bedeković, G., Fečko, P. \& Riedlová, S. (2003). Testing of coal floatability from mine Lazy, Conference Proceedings: $7^{\text {th }}$ Conference on Environment and Mineral Processing VŠBTU Ostrava, 26.-28.6.2003, pp. 397 - 402. Ostrava. 
Table 3. Flotation results with pyrolytic oils and Montanol (1:1)

\begin{tabular}{|c|c|c|c|}
\hline Flotation collector & & $\begin{array}{c}\text { Yield } \\
\%\end{array}$ & $\begin{array}{c}\text { Ash content } \\
\%\end{array}$ \\
\hline GSP 16+Mont. 1:1 & $\begin{array}{l}\text { Concentrate } \\
\text { Tailings } \\
\text { Input }\end{array}$ & $\begin{array}{r}93.64 \\
6.36 \\
100 \\
\end{array}$ & $\begin{array}{l}11.02 \\
64.66 \\
14.43 \\
\end{array}$ \\
\hline GSP 17+Mont. 1:1 & $\begin{array}{c}\text { Concentrate } \\
\text { Tailings } \\
\text { Input }\end{array}$ & $\begin{array}{c}95.68 \\
4.32 \\
100\end{array}$ & $\begin{array}{l}10.7 \\
78.35 \\
13.62\end{array}$ \\
\hline GPR 18+Mont. 1:1 & $\begin{array}{l}\text { Concentrate } \\
\text { Tailings } \\
\text { Input }\end{array}$ & $\begin{array}{r}94.63 \\
5.37 \\
100\end{array}$ & $\begin{array}{l}9.31 \\
89.16 \\
13.6\end{array}$ \\
\hline GPR19+Mont. 1:1 & $\begin{array}{c}\text { Concentrate } \\
\text { Tailings } \\
\text { Input }\end{array}$ & $\begin{array}{r}94.57 \\
5.43 \\
100 \\
\end{array}$ & $\begin{array}{r}9.83 \\
76.14 \\
13.43 \\
\end{array}$ \\
\hline 468-PO1+Mont.1:1 & $\begin{array}{c}\text { Concentrate } \\
\text { Tailings } \\
\text { Input }\end{array}$ & $\begin{array}{r}95.01 \\
4.99 \\
100\end{array}$ & $\begin{array}{l}10.43 \\
66.54 \\
13.23\end{array}$ \\
\hline
\end{tabular}

2. Crozeir, R. D.(1992). Flotation - theory, reagents and ore testing, Pergamon Press.

3. Fečko, P. (2001). Non-conventional ways of hard coal processing. VŠB-TU Ostrava, 150 pp. (in Czech).

4. Fečko, P., Riedlová, S., Pečtová, I. \& Kučerová, R. (2004). Testing of Coal Floatability from Mine CSA, Sborník: Proceedings of $10^{\text {th }}$ International Mineral Processing Symposium, Cesme, Turkey, 5.-7.X.2004, pp. 927 - 934.

5. Kme •, S. (1992). Flotation. Alfa, Bratislava, pp. 289 (in Slovak).

6. Laskowski, J. (2001). Coal Flotation and Fine Coal Utilization, Elsevier, Amsterdam, 368 pp.

7. J. Urobek, V. \& Buchtele, J. (2002). Coals, sources and processes of its processing. Ostrava, MONTANEX, $173 \mathrm{pp}$. (in Czech).

8. Sablik, J. (1998). Flotation of hard coals. GIG Katowice, pp. 291 (in Polish). 